\section{May teach you more of man}

\section{Fred S. Rosen}

Immunology in Medicine, 2nd Edn.

Edited by E. J. Holborow and

W. G. Reeves.

Grune \& Stratton: 1983. Pp.655. £55, $\$ 88$.

UNTIL recently, immunologists have in some way resembled a gaggle of mediaeval scholars bent on using established dogma to prove the existence of the deity. This scholasticism, which has been irksome to other scientists, has been relieved by the excitement generated by the applications of hybridoma technology and the great strides in understanding the complex genetics of the immunoglobulin genes, the major histocompatibility loci and the complement proteins.

The second edition of Immunology in Medicine contains very little information to guide readers through the labyrinth of these recent discoveries, even as they apply to clinical medicine. Yet this text is a very useful and compact primer for students and physicians who are seeking information about the immunological aspects of disease. Organ system by organ system, the contributors methodically cover practical information on immunological patho-

\section{ADVERTISEMENT}

\section{nature is available in Microform.}

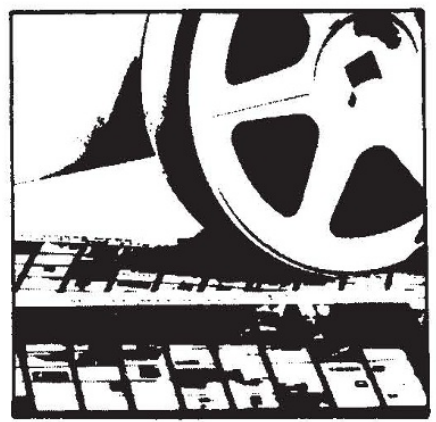

\section{University Microfilms} International

Please send additional information

for

Name

Institution

Street

City

State Z Zip

300 North Zeeb Road

Dept. P.R.

Ann Arbor, Mi. 48106 genesis, diagnosis and therapy of the whole range of immunologically related diseases. The book contains beautiful, instructive electron micrographs of mast cell degranulation and renal deposits of immune complexes and immunofluorescence of skin in immunological diseases. The text is well organized with informative tables and illustrations.

The many contributors are all wellknown specialists and practical men who have achieved a uniform succinctness in their presentations - or who have been well disciplined by the editors. The reader will have to resort to the recently published Clinical Aspects of Immunology by P.J. Lachmann and D.K. Peters or Clinical Immunology by C. Parker if they seek more detailed information, for this volume is not pallid or emasculate with tortured scholarship but rather like Wordsworth's impulse from a vernal wood.

Fred S. Rosen is James L. Gamble Professor of Pediatrics at Harvard Medical School.

\section{Setting time aright}

\section{A. Rupert Hall}

Gregorian Reform of the Calendar.

Edited by G.V. Coyne, M.A. Hoskin and O. Pedersen.

Specola Vaticana, I-00120 Città del

Vaticano, Europe: 1983. Pp.321. \$20.

ON 24 February 1582 Pope Gregory XIII (1502-1585) signed the Apostolic Letter, or Bull, Inter gravissimas, imposing a new calendar. That calendar, the Gregorian, came into force in October in countries under the Papal jurisdiction, and was adopted in Britain in 1752, in Japan in 1873, in Bolshevik Russia in 1918, in China in 1929. The event of four centuries before was celebrated in August 1982 by a meeting of historians of astronomy at the Vatican Observatory, from which this book stems.

It is well known that calendrical problems arise from the incommensurable periods of revolution of the Sun and Moon, that the timing of the recurrence of Easter is a combination of religious definition with astronomical computation, and that the Gregorian reform was made possible by possession of a more accurate measure of the length of the tropical year than had been available to Julius Caesar. But who could recite the invaluable calendrical studies of the Venerable Bede and Robert Grosseteste, here studied by $O$. Pedersen and J.D. North? Who is aware that the Gregorian leap-year rule can equally well be derived from the Alfonsine Tables and the De Revolutionibus of Copernicus? That the true author of the calendar was Luigi Giglio, who died in 1576 (G. Moyer) or that Christoph Clavius, the leading Jesuit astronomer who was mathematical head of the calendrical commission, described Copernicus as "the illustrious restorer of astronomy in this our own century, whom all posterity will celebrate and admire as another Ptolemy" (U. Baldini)?

For all who are interested in calendrical computations and their evolution this is an essential and also fascinating volume, from the able early-background article by Pedersen to the note on the Universal Calendar by F. Russo, which records the Vatican's contemporary opposition to any post-Gregorian reform which would require the intercalation of extraordinary days outside the weekly succession of Sundays.

The problems of the calendar often illustrate the truth that the best may be the enemy of the good, as when John Dee (in 1582) advised that the Gregorian discontinuity should be put at eleven days, rather than ten. The reasons for the delay in achieving a reform when the faults and their remedies were so long understood in principle were the constant pressure for more important measures of reformation in the late-mediaeval Church, and the tendency of experts to haggle over pointless details. Religious sentiments about the earliest possible date for Easter and the need to avoid synchronism with the Jewish Passover were less seriously obstructive. The Gregorian calendrical commission did of course have to decide arbitrary matters such as the date to be assigned to the vernal equinox, and the placing of "the new and full moons too late rather than too early because it would be a less error to celebrate Easter in the second month after the equinox than in the last month before the equinox" (A. Ziggelaar). The role of Copernicus is still somewhat enigmatic; he was certainly never called to Rome to give his opinion, as Galileo had it; he probably gave confidence to the reformers in the accuracy of their sums, rather than in providing new numbers.

Opposition to the Gregorian reform was based on such non-scientific arguments as the Pope's lack of authority to regulate the calendar for Protestants, the date of the equinox, and (from Michael Maestlin, Kepler's teacher) the impropriety of seeking a precise calendar when the Second Coming was hourly expected (H.M. Nobis). Tycho Brahe, Kepler and the majority of reasonable astronomers accepted the Gregorian reform as the best that was practicable (M.A. Hoskin).

Inevitably in a composite work of this kind devoted to a single historical event, there are numerous repetitions of material; not all of the papers are of equally wide interest, nor are all based on deep research. Half-a-dozen of them, however, are splendid pieces of work with their technical content plainly presented, and these will surely have a long life.

A. Rupert Hall is historical adviser to the Wellcome Trust and Emeritus Professor of the History of Science and Technology in the University of London. 